715 DECREASED HYPOCALCEMIC AND HYPOMAGNESEMIC BLEBB ING OF NEWBORN NEUTROPHILS. Alan D. Mease, Doris T. Department of Pediatrics, Uniformed Services University School of Medicine, Bethesda and Walter Reed Army Medical Center, Washington, DC.

Al though chemotactic differences between newborn (NB) and adult ( $\mathrm{AD}$ ) neutrophils (PMNs) are well documented, the cellular basis of this difference is not known and morphologic differences have not been described. PMNs were separated from anticoagulated venous blood of $10 \mathrm{AD}$ controls and the cord blood of 10 term NBs. The PMNs were suspended in protein free balanced salt solutions with and without $\mathrm{Ca}$ and $\mathrm{Mg}$ and cytocentrifuge prepara-
tions were made. The percentages of PMN with $>3$ membrane projections were determined by counting 200-300 PMNs and these PMNs were considered blebbed cells.

CONDITION

$$
\begin{aligned}
& \text { NO of EXPERIMENTAL } \\
& \text { PAIRS }
\end{aligned}
$$

Absence of $\mathrm{Ca} \& \mathrm{Mg}$ 6

Presence of $\mathrm{Ca} \& \mathrm{Mg}$ 4

$\% \pm$ SD BLEBBED PMNS $\mathrm{AD}$
$54.7 \pm 27.4$ $54.7 \pm 27.4 \quad 11.8 \pm 5.4$ In the absence of $\mathrm{Ca}$ and $\mathrm{Mg}$ the mean percentage of blebbed $\mathrm{NB}$ ans was significantly less than that of AD PMNs $(p<.005)$. Ca (ebbing in $\mathrm{AD}$ PMN to $\mathrm{NB}$ levels. These findtiona that NB PMNs have an inability to undergo conformabalo to alterations in $\mathrm{Ca}$ and $\mathrm{Mg}$ balance. Since membrane regulation of $\mathrm{Ca}$ and $\mathrm{Mg}$ flux is import ant in chemotaxis, a NB PMN membrane abnormality affecting this
Elux may be the cellular basis of the NB PMN chemotactic

\section{IDENTIFICATION OF A NEUTROPHIL MEMBRANE DIFFERENCE BETWEEN ADULT AND NEWBORN CELLS USING A LECTIN-} NDUCED ASSAY. Alan D. Mease, Gerald W. Fischer, Askold D. Mosijczuk, Frederick B. Ruymann, and Dale D. Landis. of Medicine, Bethesda and Walter Reed Army Medical Center, Washington, DC.

Intrinsic membrane differences between newborn (NB) and adul (AD) neutrophils (PMNs) have been suggested as the mechanism of decreased NB PMN chemotaxis. Using lectin-induced aggregation (AGGR) a rapid turbidometric assay was developed and demonstrat ed a difference between $N B$ and $A D$ PMN membrane characteristics. PMNs were separated from anticoagulated venous blood of $13 \mathrm{AD}$ controls and cord blood of 8 normal term NBs. With constant temperature and PMN concentration, FHA caused reproducible AGGR of both NB and AD PMNs. The rate (slope) of PMN AGGR was dependent on PHA concentration. At the optimal PHA concentration the mean percentage ( \pm S.E.M.) of NB PMN AGGR was significantly less than AD PMN AGGR (NB\%AGGR: $45.7 \pm 5.4$ vs. AD\%AGGR 62.5 \pm 1.7 , $p<.0025)$. The difference between the mean rate of $\mathrm{NB}$ and $\mathrm{AD}$ PMN AGGR was highly significant (NB slope:12.0 \pm 1.2 vs. AD slope $17.3 \pm 0.7, p<.005)$. Con A did not cause measurable AGGR of either NB or AD PMNs. Preexposure to NB plasma did not alter $A D$ PMN AGGR. These studies using PHA-induced AGGR have identified a NB PMN membrane abnormality when compared to AD PMNs. This technique may be useful in studying other disorders with neutrophil membrane abnormalities.

717 MARROW TRANSPLANTATION (MTP) IN WISKOTT-ALDRICH SYNDROME (WAS): T CELL ENGRAFTMENT WITH CYCLOPHOSPHAMID $(C Y)$, COMPLETE ENGRAFTMENT WITH TOTAL BODY IRRADIATION. H.J. Meuwissen, M.A. Kieserman, E.G. Taft, B. Pollara, R. J. Pickering. Albany Med. Coll., Birth Defects Inst. and Kidney Disease Inst., N.Y.S. Dept. of Health, Albany, N.Y. 12208.

We studied two patients with WAS who had MTP with marrow from HLA-identical siblings. The first patient received $200 \mathrm{mg} / \mathrm{kg} \mathrm{CY}$ over 4 days (Bach et al., Lancet $1: 1364,1968$ ). We have followed this patient for 7 years. He has petechiae, bleeding in joints, and severe thrombocytopenia. IgM has remained low; antibody production to some antigens, lymphocyte response to mitogens and in vitro $B$ cell functions are defective. Growth and development have been normal. The second patient received cytosine arabinoSide $5 \mathrm{mg} / \mathrm{kg} /$ day $\times 7,6$-thioquanine $4 \mathrm{mg} / \mathrm{kg} /$ day $\times 7$, and $\mathrm{CY} 50 \mathrm{mg} /$ $\mathrm{kg} /$ day $\times 4$ prior to MTP. In both patients after MTP, megakaryocytes, red cells, neutrophils, macrophages, and most $B$ cells remained of recipient type while most $T$ cells were of donor type. The second patient was retransplanted after preparation with anti-lymphocyte globulin, $2 \mathrm{ml}$ IV daily $x 4$, Procarbazine, 12.5 $\mathrm{mg} / \mathrm{kg} /$ day $\times 3$, and $800 \mathrm{R}$ total body irradiation. Ninety days
after the 2 nd transplant, all nucleated marrow and blood including $B$ and $T$ cells were of donor type; WBC 12,500 , platels, $132,000 / \mathrm{nm}^{3}$, hemoglobin $9.8 \mathrm{gms} \%$ and reticulocytes $3.5 \%$. No graft-versus-host disease was observed. We conclude that in marrow transplantation for WAS, $200 \mathrm{mg} / \mathrm{kg}$. CY may be inadequate preparation. In WAS, $\mathrm{T}$ cells may more readily be engrafted than ther blood cells. Supported by USPHS GCRC \#M0-1-R00749-05. John J. Miller III, Richard B. Moss, Yao-P1 Hsu, and
Angela Koken. Stanford University School of Medicine, Children's Hospital C Stanford, Dept. of Pediatrics, Palo Alto Arroyave's method for the detection of $\mathrm{C} 3 \mathrm{c}$ and $\mathrm{C} 3 \mathrm{~d}$ by counte immunoelectrophoresis (J. Immunol. Methods, 13:101, 1976) has been used to study plasma from children with various rheumatic diseases over a period of 18 mos. Eleven of 11 children with active SLE had $(+)$ tests. Plasma from 2 of 5 children with clinically inactive SLE were $(+)$. Variations with time confirmed Arroyave's finding that ( + ) tests are sensitive indicators of disease activity in SLE. Plasma from 1 child with MCTD was transiently $(+)$. Consistently $(-)$ tests were found in 7 children with dermatomyositis and 2 with scleroderma. On 1 occasion, 1 of 5 children with ankylosing spondylitis had a $(+)$ test. Thirty of 74 children with JRA were $(+)$ on one or more occasions. By mode of onset these were: 6 of 14 systemlc, 13 of 27 polyarticular and 11 of 33 pauctarticular. Six of 8 latex fixation $(+)$ patients had $(+)$ tests. Correlations with sedimentation rates or other measures of disease activity were not clear. One traumatic knee effusion and synovial fluid from 2 children with pauciarticular, plasma (-) JRA had (-) tests for C3c and C3d. Synovial flutd and plasma from 1 child with Jacob's "Streaking Leukocyte Syndrome" were $(+)$

This data is consistent with other work indicating that some, but not all, children with JRA have antigen-antibody complexes in blood or elsewhere which are capable of activating complement.

\section{9} CELL ELASTIMETRY IN THE CHARACTERIZATION OF DISUCLA School of Medicine at Harbor Gichael E. Miller, of Pediatrics, Torrance, California 90509

Although clinically similar, disorders of neutrophil (PMN) movement are heterogeneous and involve a number of separable mechanisms. The characterization of these mechanisms has been 1 imited by available research techniques. We recently described the application of cell elastimetry to the study of normal PMN motuiry. The assay, which measures amounts of negative pressure an est imate of deformability of the PMN. In normal PMNS, deforma bility has similar Cat+, energy (glycolysis), $\mathrm{pH}$, temperature and contractile protein requirements to those of normal Boyden chamber chemotaxis. It was, therefore, suggested that the assay might provide an important probe in the study of abnormal PMN motility. We now report the first such studies. PMNS from subjects with recognized abnormalities of motility including normal neonates and children with lazy leukocyte syndrome, diabetes mellitus, familial chemotactic deficiencies, sporadic chemotactic defici cles and hyper-IgE-eczema-infection syndrome were studied in 3 assays: chemotaxis (Boyden chamber); chemokinesis (capillary tube migration); and deformability (elastimetry). The data showed: 1) marked heterogeneity existed among PMN profiles obtained from the varlous subject groups; 2) a strong correlation existed besis and deformability; 3) the only condition in whichemoklnewas and tients with the decreased but deformability normal was in 5 pa tients with the hyper-IgE syndrome. This strongly suggests Since elastimetry is since elastimetry is a single cell assay, it lends itself ideally abnormal states.
720 FHE EFFECT OF VIRAL INFECTION ON THE ABILITY OF HUMAN 20 IITOGEN STIMULATION in vitro. James $E$. Nagel, $F$. Joseph Chrest, William H. Adler, and Mathuram Santosham. Gerontology Research Center, NIA, NIH, and Department of Pediatrics, Baltimore City Hospitals, Baltimore, MD.

Using a plaque forming cell (PFC) assay system the effects of clinically and laboratory diagnosed viral illness were determinec on the ability of human peripheral blood lymphocytes to be stimulated with the mitogens phytohemagglutinin (PHA), pokeweed (PWM) antigens candida (C) and tetanus-diphtheria toxoids (Td). In coptrast with control subjects who had a geometric mean 7 PFC's/ 10 cells, children with viral infections had a mean of 1188 PFC $10^{6}$ cells for unstimulated cultures. PWM was found to be the most effectjue PFC stimulant in control subjects (geometic mean $1995 \mathrm{PFC} / 10$ cells); however concurrent viral infection resulted in a reduced number (geometric mean $267 \mathrm{PFC} / 10^{6}$ cells) of PWM induced PFC's when compared with background. Control subjects produced no PFC's in response to PHA, Con A, LPS, Td, SPA or $C_{\text {; }}$ how ever, children with rubella and disseminated herpes infection had PFC's with these mitogens, although again the absolute numbers were less than the unstimulated control cultures. These results eral blood lymphocyte subpopulation composition and function, reducing the effect of the mitogens on cellular differentation. Alternatively, direct virus-B cell interaction may result in Alternatively, direct virus-B cell interaction may result in
differentiation to immunoglobulin producing cells without a mitogen-T-B cell interaction. 